\title{
Public Debt Management and Macroeconomics Policies Coordination: Evidence from Jordan
}

\section{Gestión de la deuda pública y coordinación de políticas macroeconómicas: evidencia de Jordania}

Received: November 2, 2020

\begin{abstract}
This study aimed to analyze the effects of fiscal and monetary policies interactions on public debt in Jordan during (1970 - 2019). Using Vector Error Correction Model (VECM) derived from VAR (Vector Auto regression), and examine dynamic interactions between economic variables over time, by Appling Impulse Response Function, and Variance Decomposition. The results indicated that the fiscal policy instruments affect public debt in two different directions, the expansion of government expenditure positively affect public debt, while tax revenues reduce indebtedness. The monetary policy instruments affect public debt in the same directions, as the results indicated that the central bank in controlling money supply and managing interest rate helps the fiscal authority in reducing the public debt in Jordan. The results confirm the strongest impact of government expenditure on public debt in Jordan. The study recommends the necessity of rationalizing government expenditures and combating tax evasion. In addition, more coordination between fiscal and monetary policies.
\end{abstract}

Keywords: Jordan; Public Debt; Monetary policy; Fiscal policy; Policies coordination; VECM.
Accepted: December 12, 2020

\section{Resumen}

Este estudio tuvo como objetivo analizar los efectos de las interacciones de las políticas fiscal y monetaria sobre la deuda pública en Jordania durante (1970 - 2019). Se aplicó el Modelo de corrección de errores vectoriales (VECM) derivado de VAR (Regresión automática vectorial) y examine las interacciones dinámicas entre las variables económicas a lo largo del tiempo, aplicando la función de respuesta al impulso y la descomposición de la varianza. Los resultados indicaron que los instrumentos de política fiscal afectan la deuda pública en dos direcciones distintas, la expansión del gasto público afecta positivamente la deuda pública, mientras que los ingresos tributarios reducen el endeudamiento. Los instrumentos de política monetaria afectan la deuda pública en la misma dirección, ya que los resultados indicaron que el banco central en el control de la oferta monetaria y la gestión de la tasa de interés ayuda a la autoridad fiscal a reducir la deuda pública en Jordania. Los resultados confirman el impacto más fuerte del gasto público en la deuda pública en Jordania. El estudio recomienda la necesidad de racionalizar el gasto público y combatir la evasión fiscal. Además, una mayor coordinación entre las políticas fiscal y monetaria.

Palabras llave: Jordan; La deuda pública; La política monetaria; La política fiscal; Coordinación de políticas; VECM

\section{Introduction}

Jordan started borrowing abroad to finance budget deficit. As a result, Jordan reached a high level of indebtedness and faced a debt crisis in 1989. At the end of 2019, Public debt reached $95 \%$ of GDP, the ratio of external debt to GDP (39\%), the ratio of domestic debt to GDP (65\%) (Central Bank of Jordan,

\footnotetext{
${ }^{14}$ Assistant Professor, Department of Finance and Banking, College of Business Administration, Dar Aluloom University, Riyadh,
} KSA. 
2019). Reinhart and Rogoff (2010 a) emphasized that in developed and developing economies when the ratio of public debt to GDP is above $90 \%$, this leads to a $1 \%$ drop in economic growth rates. When the external debt ratio reaches $(60 \%)$ of GDP, economic growth will decrease by $(2 \%)$. In addition, Reinhart and Rogoff (2010 b) emphasized that there is a strong relationship between banking crises and sovereign default debt in many developed and emerging countries. Often banking crises precede or accompany debt crises. Public borrowing accelerated significantly before the debt crisis. In addition, governments often have "hidden debts" that exceed the documented levels of external debt.

Domestic debt in Jordan represents the existing outstanding of the central government debt, includes the government bonds and bills, in addition to the outstanding of direct credit facilities that the government obtains from the banking system or non-bank sources.

Jordan began borrowing domestically in 1969; the government began borrowing by buying bonds in 1971 . In 1999, the treasury began to borrow domestically by the treasury bills. The central bank issues it on behalf of the treasury.

Public debt management is part of the integrated financial management of the Government and is closely linked to budget and treasury operations, where the way of financing is a significantly matters. Among the various alternatives, public debt is the important way of financing public expenditures in Jordan.

In 2001, Public Debt Management Law was issued; the most prominent feature is that domestic borrowing limited in instruments such as Treasury bill and Bonds, to enhanced government bond market development and financial sector. The law also set ceilings for public debt that do not exceed $60 \%$ of GDP for each domestic and external debt, prevent government borrowing from commercial banks, and but restrictions on borrowing from the central bank.

Jordanian government adopted a set of policies aimed to reduce external debt and its burdens, such as; rescheduling external debts, restructuring commercial debts, buying, swaps and canceling some external debts. Despite the reforms, debt burdens have increased in recent years, in 2019 public debt service to GDP and total revenues reached $(9 \%),(36 \%)$, respectively (Ministry of Finance, 2019). The International Monetary Fund (IMF) report pointed to the increase in public debt in Jordan, and recommended fiscal consolidation and growth-enhancing reforms to ensure that debt on a steady downward path. This requires achieving a budget surplus about $2 \%$ of GDP by 2022, and removing tax exemptions on income and consumption, in addition to strong efforts to rationalize current expenditures in light of the anticipated financing policies and committed policies, (International Monetary Fund, 2019)

Traditionally, debt management policy was not considered a separate macroeconomic Policy, but was subordinated to fiscal and monetary policies. Effective debt management should include a nation's borrowing strategy, estimation and determining the official levels of borrowing, forming an appropriate structure, and purpose-oriented use of borrowed resources and control of the effectiveness of their usage (Slav'yuk and Slaviuk, 2018).

Debt in foreign currency also has its risks and can lead to pressure on the exchange rate or monetary policy. By reducing, the risk in which government debt portfolio will become a source of instability, prudent management of government debt, can make economies less exposed to damage and financial risk (Gaber et al., 2013). The rise in debt in Jordan reached 202\% of GDP in 1988, and the increase in debt service, led to exchange rate crisis in 1988-1989. In other words, the expansionary fiscal policy led to budget deficit, financed by domestic and external borrowing. This leads to weak the ability of the monetary authority to achieve monetary policy objectives.

The coordination between monetary and fiscal policies relates to the financing budget deficit. The monetary policy affects the capacity of the government to finance budget deficit by changing the cost of debt service and by limiting or expanding sources of financing. The government's financing needs will also restrict the independence of the monetary authority (Laurens and Piedra, 1998).

While fiscal policy has a direct impact on public debt management, monetary policy can play an important supporting role (Moore \& Skeete, 2010). However, Public debt management is important because the size and the maturity of public debt affect future fiscal and monetary policy decisions, therefore the coordination between fiscal and monetary policies becomes inevitable. Nevertheless, monetary and fiscal policies are 
implemented by different government authorities, each with its own objectives and instruments. Central bank actions may affect debt management of fiscal authority and deficits. On the other hand, the Ministry of Finance's actions may also affect the monetary policy and its objectives. This paper aims to study the coordination between monetary and fiscal policies in Jordan and their effects on public debt, using statistical procedures.

\section{Literature Review}

Theoretical and empirical literature focuses on the macroeconomic policies and public debt, adopted the Keynesian theory, which is government can control aggregate demand and the level of national income through fiscal policy instruments. Since government, budget deficits or surplus (BD) is the difference between its public expenditure $(\mathrm{G})$ and tax revenues $(\mathrm{T})$. That is, $B D=G-T$. so public debt can derived as $D=(1+r) D+B D$, the public debt formulate as: $D=D t+r D t+G t-T t$, that means the public debt accumulation is the total of all deficits or surplus budget components at time $(\mathrm{t})$, and interest payments on public debt ( Mah et al. 2013). Either public expenditures can be financed by issuing money or debt, the rate of interest on public debt ( $\mathrm{r}$ ) is under the control of the monetary policy, as a macroeconomic policy (Hein, 2018).

The traditional view of public debt and fiscal policy, assumed that economies tend to operate with full employment and thus fiscal expansion is likely to lead to higher inflation. Within this framework, spending cuts ultimately lead to lower inflation and lower public debt (Ribeiro \& Lima, 2019). Contrary to the traditional view of public debt, the post-Keynesian growth literature has extensively discussed the importance of a more proactive fiscal policy on issues such: economic stability, income distribution, and public debt (Favero \& Giavazzi, 2007; Hein, 2018; Ribeiro \& Lima, 2019). However, the literature ignored the potential impacts of public debt when it estimates the effects of fiscal policy on macroeconomic variables (Teles \& Mussolini, 2014).

Both fiscal policy instruments adjusted over time in order to stabilize the public debt (Favero \& Giavazzi, 2007). The empirical literature results supported the positive relation between the budget deficit and the public debt (Bader \& Magableh, 2009; Pirtea et al. 2013; Mah et al. 2013; Belguith \& Omrane, 2017). Thus, indicate that fiscal policy instruments respond to the level of the debt (Favero \& Giavazzi, 2007). The empirical studies by (Mah et al. 2013; Uguru, 2016; Waheed, 2017; Alawneh (2017); Iiyambo and Kaulihowa, 2020) confirmed the significant positive relationship between public expenditure and public debt, further studies by (Oladokun, 2015; Uguru, 2016; Iiyambo \& Kaulihowa, 2020) revealed the existence of a unidirectional causality between public expenditure and public debt. On the other hand, Hakhu (2015) showed that random expenditure cuts cannot help to stabilize public debt, but increasing capital expenditures can stabilize public debt in the long run. Ribeiro and Lima (2019) confirmed that conducting a restriction on public expenditure is likely to enhance the conditions for stabilizing the public debt. Perhaps, in developing countries, restrictions on public expenditure may not be sufficient to stabilize public debt.

Dungey and Fry (2007) showed the importance of tax revenues to reduce public, so public debt responded strongly to changes in tax revenue. Therefore, tax evasion could increase the public debt. Menguy (2020) linked between tax and public debt levels in the monetary union countries. Also validated the negative relation between taxation rates and public debt levels. Le Van et al (2019) found that domestic debt unambiguously increases with tax whereas external debt displays an inverted U-shaped curve. A high tax rate leads to a reallocation of public debt in favor of domestic debt to the detriment of external debt. Ribeiro \& Lima (2019) indicates that a more progressive tax structure may often increase the chances of stabilizing public debt in the long run. In addition, a less regressive tax structure may increase the system's propensity to have stable public debt. Doi, et al (2011) found that the fiscal policy is "active" the tax revenues do not rise when the debt increases. As well, Romer and Romer (2010) indicated that the effect of tax shock on economic growth depends on whether the taxation is with the government's desire to stabilize the public debt, or is unrelated to the fiscal policy.

Gaber et al. (2013) present potential danger for the public debt explosion. It intends to explain the government goal for borrowing money at lowest rate and sustain the fiscal stability. Meliz (1997) showed fiscal policy responds to public debt in a stabilizing manner. The study also demonstrated the importance of fiscal policy to achieve economic stability, as tax Countercyclical, the public expenditure is Pro-cyclical. When public debt to GDP ratio is high, the countercyclical fiscal policy becomes stronger (Mason \& 
Jayadev, 2018). Higher levels of public debt make it more optimal to reduce public expenditure, in order to reduce the negative effects of taxes (Adam, 2011).

The issue of the role of monetary policy in managing public debt has not been sufficiently addressed in the theoretical and empirical literature, while practice shows that it is, in fact, very important (Golomejic, 2007), developing countries have attempted to use monetary policy to stabilize debt (Moore \& Skeete, 2010).

The most simplistic model, that explained the links between, debt management, monetary and fiscal policies, it is to use government budget constraint (Blommestein, \& Turner, 2012): $(B D t)=(B t-B t-1)+$ $(M t-M t-1)$ shows that the budget deficit $(\mathrm{G}-\mathrm{T})$, must be financed either by issue debt $(\mathrm{Bt}-\mathrm{Bt}-1)$ or by loans, or issuing money, that will rise the monetary base (Mt-Mt-1), The budget deficit puts pressure on the monetary policy to monetize the debt, which will ultimately lead to an increase in the money supply (Mah et al. 2014). The deficit would also provide the financial market with the necessary short-term debt instruments for open market operations that affect liquidity in the financial market. Therefore, debt management and monetary policy conduct are closely related (Basyal, 2007).

Silva, et al (2014) studied the effects of public debt management on macroeconomic equilibrium in Brazil economy. The results indicated that monetary policy influenced debt management process. Printing money is one of the policies used by monetary authorities to finance debt on request by fiscal authorities. Therefore, the need of government borrowing is an important factor affects the money supply, and changes in the money supply be thought as monetary policy (Moore, \& Skeete, 2010). The increase in the cost of public debt can be explained by the rise in the interest rate (Pirtea et al. 2013; Belguith \& Omrane, 2017).

Interest rates and seignorage significantly affect public debt, because interest rates changes the demand for credit and seignorage directly finances the deficit. Dungey and Fry (2007) showed that monetary policy is a catalyst for fiscal policy to reduce the public debt through interest rates. Therefore, Fiscal and monetary policy reduced GDP when it aimed to reduce inflation and public debt. Also, found that Fiscal consistency and harmonization of growth factors and monetary policy are necessary for effective debt management. Thus debt management usually focus on keeping government debt markets liquid, limiting refunding risks, (Blommestein \& Turner, 2012), emphasized that high government debt will create complex interactions between debt management and monetary policy, while, Alfonso, Alves and Balhote (2019) assumed an active role of Central bank in cases of higher levels of debt. Further, debt service payments a key issue in debt, the study by Moore \& Skeete (2010) provides that negative monetary policy shocks could significantly increase the cost of servicing government debt in Barbados. Hodula and Melecky (2020) Found that a tighter monetary policy increases the risk of government debt cost. Cavalcanti et al, (2018) studied the macroeconomic effects of monetary policy shocks when fiscal rules are constrained to ensure public debt sustainability, the rise in the interest rate followed a monetary policy shock increased the cost of financing debt, thereby making a fiscal adjustment necessary to debt sustainability. Therefore, emphasis should be placed on using public debt as a financial instrument in a correct manner, and on keeping interest rates low (Hasan et al, 2020).

Monetary and fiscal authorities should be coordinate to maximize the effects of fiscal and monetary policy instruments on debt management. Without sound policies, effective management of debt can only be an afterthought. The nature of coordination among the macroeconomic policies are varied in every economy (Niemann \& Hagen, 2008). Researchers interested to estimate the interactions between fiscal and monetary policy add some variables that have a direct relationship with the interaction of the two policies, such as economic growth, inflation, budget deficit, and public debt. Laurens, and Piedra (1998) reviewed the institutional arrangements of monetary policy, which aimed to isolate the central bank from deficit financing required by the fiscal authority. Togo (2007) established public debt management as a separate policy with a different objective from fiscal and monetary policies, and integrated public debt management into a macroeconomic framework analysis. He also illustrated the importance of policy separation and the consistent coordination between policies.

The study by Kirsanova et al. (2005) showed that in the presence of high inflation, the fiscal policy controlled public debt and let monetary policy carried the burden of re-economic stability. Claeys (2006) concluded that fiscal policy stabilizes public debt, and point out the significant interaction between fiscal and monetary policies through the debt channel. (Nasir et al, 2010) investigated the coordination among the fiscal and monetary policies in Pakistan, confirmed the weak coordination among the policies. The 
dynamic of public debt management should become a priority for both creditor and debtor countries (Pascal, 2011) Golomejic (2012) explained the main characteristics of coordination between monetary and public debt management policies in Croatia. National Bank improved the coordination with the public debt management policy. Demind (2018) used annual panel data of 42 countries, and found an increased in the degree of coordination between countercyclical monetary and fiscal policies. Guler (2019) showed that Monetary and fiscal policies in Turkey are could not be completely independent of each other in terms of their effect, the monetary authority's action affect the financing cost of the budget deficit by changing interest rates, and the public debt.

Rezabek, and Doucek (2018) analyzed the interactions between monetary and fiscal policy in Czech, the results pointed the lack of complementarity between policy actions adopted by the authorities. Siddiqui (2019) discussed issues of public debt and austerity policy in UK, where the rise in public debt as a matter of concern, and austerity policies have been proposed to reduce public debt.

Finally, it can be said that policymakers must respond to changing circumstances in their tax base and the cost of government financing and spending. Policy inclusion calls for effective public debt management strategies and government spending management frameworks supported by sustainable revenue prospects and money supply monitoring to provide fiscal and monetary sustainability to boost economic growth in developing countries (Collignon, 2012)

\section{Methodology and Model Specification}

To Estimate the effects of interactions between fiscal and monetary policy and public debt, the study flowing: (Ludvigson, 1996; Lockwood et al, 1996; Mah et al, 2013) describes the accumulation of public debt as. : $D=(1+r) D+G-T$, rewrite the equation given as:

$$
D_{t+1}=D_{t}+r_{t+1} D_{t}+G_{t}-T_{t}
$$

For simplicity the stock of debt at the beginning of period $(D t)$ depends on the stock of debt at the beginning of the last period, $D t-1$, the flows occur between $t-1$ and $t$, the interest rate, government expenditure, and $\operatorname{tax}(\mathrm{T})$, the equation set as the following form:

$$
D_{t}=D_{t-1}+r_{t-1} D_{o}+G_{t-1}-T_{t-1}
$$

Flowing (Mah et al. 2013; Belguith and Omrane, 2017; Alalaya et al., 2017). The study use VAR (Vector Autoregression), which is one of the models used to study the dynamics of interactions between a set of economic variables over time. The model consists of a system of functions that treated symmetrically, so that each variable written in the form of a function in itself with lags, and all other variables in the system with lags, that is, each function specifies the same explanatory variables (Hamilton, 1994). This model used as an alternative to simultaneous equations method. There are no exogenous variables, and all variables treated as Lagged Endogenous Variables (Thomas, 1997). This model requires determining the variables that expected to interact with each other, and which chosen based on the economic relations between the variables according to economic theory and practical studies, and requires determining the number of variables time lagged. Which will reflect accuracy of estimates of models used in study.

For a set of (n) time series variables $x_{t}=\left(x_{1 t}, x_{2 t}, \ldots, x_{n t}\right)^{\prime}$, a VAR model of order $\mathrm{p}(\operatorname{VAR}(\mathrm{p}))$ can be written as:

$$
X_{t}=A_{1} X_{t-1}+A_{2} X_{t-2}+\ldots+A_{p} X_{t-p}+u_{t}
$$

Where the $A_{i}$ 's are (nxn) coefficient matrices and $u_{t}=\left(u_{1 t}, u_{2 t}, \ldots, u_{n t}\right)^{\prime}$ is an unobservable zero mean error term. 


$$
D_{t}=\delta_{y} Y_{t-i}+\delta_{d} D_{t-i}+\delta_{g} G_{t-i}+\delta_{t} T_{t-i}+\delta_{m} M_{t-i}+\delta_{r} R_{t-i}+\varepsilon_{3 t}
$$

Where represents the vector of variables used to estimate, and can be rewritten as follows:

$$
X_{t}=\left[D_{t}, Y_{t}, G_{t}, M_{t}, T_{t}, R_{t}\right]
$$

$D_{t}$ : Refers to the outstanding public debt. $Y_{t}$ : Gross domestic product (GDP) $G_{t}$ : Government expenditure. $M_{t}$ : Money supply $T_{t}$ : Tax revenues. $R_{t}$ : Interest rate.

The presence of lags for variables in the model makes this model suitable for analyzing the transition mechanisms of fiscal and monetary policies effects, as it has been assumed that there is a difference in policy effect, monetary policy suffers from (effect lag) and fiscal policy suffers from (Implementation lag), which means that the effect of fiscal and monetary policies on economic variables takes time.

If the variables in the model are jointly integrated, the Vector Error Correction Model (VECM), which is a restricted model for the VAR model, can be used in order to determine the direction of causality and estimate the adjustment velocity, i.e. short-run disequilibrium to long-run equilibrium among the variables (Jang and Ogaki, 2004).

The advantage of this method is that it relates the causal relationship to the co-integration analysis. If the co-integration test indicates the existence of a relationship between two variables in the long-run, then causality must exist at least in one direction, but this cannot always be discovered if the results are based on the Grainger causality test, the direction of the relationship can be determined by using (VECM) model. In addition to determining the direction of the relationship between the variables, (VECM) model enables us to extract the (EC) to identify the size and nature of the effect of each variable on other variables in the model through analysis of the Variance Decomposition, and Impulse Response Function (IRF).

\section{Empirical Results and Interpretations}

In VAR model, all variables must be stationary before the analysis, Augmented Dickey-Fuller (ADF) (Dickey and Fuller, 1981) unit root test performed in order to determine whether the variables are stationary. To determine whether the variables (X) are stationary or not, Augmented Dickey-Fuller (ADF) test use based on the regression equation with the inclusion of intercept and a trend form:

$$
\Delta X_{t}=\alpha_{0}+\beta T+\delta X_{t-1}+\sum_{j=1}^{m-1} \beta_{j} \Delta X_{t-1}+\varepsilon_{t}
$$

This test used to avoid spurious correlation between variables due to the stationary of the time series. In the absence of stability, a recipe (Stationarity), the gradient which is obtained between the variables of time series is often false although the probability of getting a high value of the coefficient of determination $\left(R^{2}\right)$.

This is due to the time that the data there is often a factor of (Trend), which reflects the particular circumstances affecting all the variables in the same direction or in opposite directions.

Tables (1) show the results of unit root tests using ADF test for time series variables are nonstationary in their levels but stationary in their first differences, which means that the time series under study are integrated from the first order I(1). The null hypothesis was rejected in the presence of nonstationary or by the presence of the unit root of the first difference of time series levels at a significant level (5\%), whether with a time series intercept or if there is an intercept and trend. 
Table 1.

Augmented Dickey-Fuller Test.

\begin{tabular}{|c|c|c|c|c|}
\hline \multirow{2}{*}{ Variable } & \multicolumn{2}{|l|}{ Level } & \multicolumn{2}{|l|}{$1^{\text {st }}$ difference } \\
\hline & Intercept & $\begin{array}{l}\text { Trend and } \\
\text { Intercept }\end{array}$ & Intercept & Trend and Intercept \\
\hline $\mathrm{D}$ & $2.569708^{*}$ & 0.716213 & $-2.774095^{*}$ & $-2.768843^{*}$ \\
\hline G & $2.750105^{*}$ & -0.445348 & $-3.177003^{*}$ & $-4.241419^{*}$ \\
\hline $\mathrm{T}$ & 2.196682 & -0.589278 & $-3.101498 *$ & $-3.856295^{*}$ \\
\hline M & 1.944200 & -0.462019 & -1.782238 & $-2.922647 *$ \\
\hline $\mathrm{R}$ & $-2.348029 *$ & $-2.330442 *$ & $-3.696199 *$ & $-3.701646^{*}$ \\
\hline GDP & 2.360194 & 0.178142 & -1.217577 & $-2.313017^{*}$ \\
\hline
\end{tabular}

* Means that it is significant at the level of 5\%

To determine the optimal number of times lags, usually tests used globally and the most important are: (AIC) (Akaike Information Criterion), (SC) (Schwartz's Criterion). This study identified two time lags.

Testing for co-integration is a necessary step to establish if a model empirically exhibits meaningful long run relationships. A co-integration test is used to find out the nature of the equilibrium relationship between variables in the long run, by using Maximum Likelihood method (Johansen and Juselius, 1990). The method of joint integration refers to the equilibrium relationship between variables in the long run. The Johansen test is applied in the event that the variables exceed two variables due to the possibility of multiple vectors for joint integration. The co-integration test is preferred in cases involving only two variations over the twostep Engel-Grainger method.

The results in table (2) of the Joint Integration Test (Trace Test) and (Maximum Eigenvalue), showed the existence of three complementary relationships, thus the time series variables in this study are considered integrated. This indicates that there are long-term equilibrium relationships between the variables.

Table 2.

Co-integration Test.

\begin{tabular}{llllc}
\hline & Likelihood & 5 Percent & 1 Percent & Hypothesized \\
\hline Eigenvalue & Ratio & Critical Value & Critical Value & No. of CE(s) \\
0.821890 & 179.8358 & 82.49 & 90.45 & None ** \\
0.601635 & 97.01889 & 59.46 & 66.52 & At most 1 ** \\
& & & \\
0.535631 & 52.84031 & 39.89 & 45.58 & At most 2** \\
0.212222 & 16.02070 & 24.31 & 29.75 & At most 3 \\
0.082165 & 4.570856 & 12.53 & 16.31 & At most 4 \\
0.009443 & 0.455428 & 3.84 & 6.51 & At most 5 \\
$*(* *)$ denotes rejection of the hypothesis at 5\%(1\%) significance level & \\
L.R. test indicates 3 cointegrating equation(s) at 5\% significance level & \\
\hline
\end{tabular}

If there is a co-integration relation between two variables, there is unidirectional causality Granger at least. If there is Granger causality relation between variables, the co-integration test cannot determine the direction of causality relationship. Engle and Granger (1987) indicated that if there is co-integration relation between two variables $\mathrm{X}$ and $\mathrm{Y}$, there is always a vector correction model between them. Therefore, (VECM) should be used to investigate causality relationship. The VAR model can be rewritten as a (VECM) from (Oxley \& Greasley, 1998): 


$$
\Delta X_{t}=\alpha_{0}+\sum_{i=1}^{m} \alpha_{i} \Delta X_{t-i}+\sum_{j=1}^{n} \alpha_{j} \Delta X_{t-j}+\delta E C M_{t-1}+U_{t}
$$

VECM for two variables $\mathrm{X}$ and $\mathrm{Y}$ can be illustrated by using two equations as follows (Oxley and Greasley, 1998):

$$
\begin{gathered}
\Delta Y_{t}=a_{0}+\sum_{i=1}^{m} b_{i} \Delta Y_{t-1}+\sum_{j=1}^{n} c_{j} \Delta X_{t-1}+d E C M+\varepsilon_{1 t} \\
\Delta X_{t}=\alpha_{0}+\sum_{i=1}^{m} \beta_{i} \Delta Y_{t-1}+\sum_{j=1}^{n} \beta_{j} \Delta X_{t-1}+\delta E C M+\varepsilon_{2 t}
\end{gathered}
$$

Where: (x) the vector represents the variables used in the estimation, $\Delta$ the first difference is the error term, and $(\mathrm{m})$ and $(\mathrm{n})$ represent the periods of time lags. The ECT represent the long run effect of one variable on the other while the changes of the lagged independent variable describe the short-run causal effect. ECM finds the speed at which the disequilibrium is adjusted in the long run. The negative sign of this parameter indicates that any economic shock that takes place in the short run will be adjusted in the long run.

The results of estimating (VECM) in the equation of public debt showed that error correction term (ECT) significant and negative, and its value is low and indicates low speed of adjustment indicates that $6.6 \%$ of disequilibrium public debt in Jordan will converge to the equilibrium by $6.6 \%$ in the following year due to the change in the public debt itself, and fiscal and monetary policy variables (public expenditures, tax revenues, money supply, interest rate), and economic growth. The estimates also indicate a positive impact of government expenditures on debt, and negative impact of tax on debt in short run but not significant. Money supply has a positive impact on public debt in the short run.

Table 3.

Results of VECM Estimates.

\begin{tabular}{lccc}
\hline Variables & Coefficient & Standard errors & t-statistics \\
\hline EC & -0.065722 & $(0.04232)$ & $(-1.55290)^{*}$ \\
D(D(-1)) & 0.250802 & $(0.15890)$ & $(1.57836)^{*}$ \\
D(D(-2)) & 0.271729 & $(0.16639)$ & $(1.63311)^{*}$ \\
D(G(-1)) & 0.292611 & $(0.60063)$ & $(0.48718)$ \\
D(G(-2)) & 0.183768 & $(0.55106)$ & $(0.33348)$ \\
D(T(-1)) & -0.116789 & $(0.66275)$ & $(-0.17622)$ \\
D(T(-2)) & -0.119346 & $(0.56048)$ & $(-0.21294)$ \\
D(M(-1)) & -0.977857 & $(0.33653)$ & $(-2.90571)^{*}$ \\
D(M(-2)) & -0.063048 & $(0.33673)$ & $(-0.18723)$ \\
D(R(-1)) & 1.918037 & $(0.20277)$ & $(-0.00944)$ \\
(R(-2)) & -3.50920 & $(0.35112)$ & $(-15103)$ \\
D(GDP(-1)) & 0.986655 & $(0.32766)$ & $(3.01123)^{*}$ \\
D(GDP(-2)) & 0.710165 & $(0.45393)$ & $(1.56447)^{*}$ \\
\hline
\end{tabular}

* Means that it is significant at the level of 5\%

To determine the direction of the relationship between the variables, whether they are non-causing, unidirectional or bidirectional. If there are two variables $(\mathrm{X})$ and $(\mathrm{Y})$, then the variable $(\mathrm{X})$ causes the variable $(\mathrm{Y})$ if the time deceleration of the variable $(\mathrm{X})$ has additional predictive on the variable $\mathrm{Y}$ when adding the time deceleration of the variable $\mathrm{X}$ to the time deceleration of the values of $\mathrm{Y}$ itself). To determine the direction of causation, the Granger Causality test usually used as follows (Stock and Watson, 2001):

$$
X_{t}=\sum_{i=1}^{m} a_{i} X_{t-i}+\sum_{j=1}^{n} b_{j} Y_{t-j}+U_{t}
$$




$$
Y_{t}=\sum_{i=1}^{r} c_{i} Y_{t-i}+\sum_{j=1}^{s} d_{j} X_{t-j}+V_{t}
$$

$\mathrm{X}$ causes $\mathrm{Y}$ if the following null hypothesis is rejected $\mathrm{H} 0: \mathrm{d}=0, \mathrm{j}=1$

Y causes $\mathrm{X}$ if the following null hypothesis is rejected: $\mathrm{H} 0: \mathrm{b}=0, \mathrm{j}=1$. If both (1) and (2) achieved, there is a bidirectional causal relation.

The results of causality test in table (4) showed a unidirectional causal relation between fiscal policy (government expenditure, tax) and public debt in Jordan. Monetary policy, results indicates the existence of a unidirectional causal relation between money supply and the Jordanian public debt. The results do not indicate the existence of causal relation between the interest rate and the Jordanian public debt during the study period.

Table 4.

Granger causality test.

\begin{tabular}{|c|c|c|c|}
\hline Null Hypothesis: & Obs & F-Statistic & Probability \\
\hline G does not Granger Cause D & & 5.80939 & 0.00584 \\
\hline D does not Granger Cause $G$ & & 0.97914 & 0.38385 \\
\hline $\mathrm{T}$ does not Granger Cause D & & 3.80920 & 0.02999 \\
\hline D does not Granger Cause T & & 0.58553 & 0.56119 \\
\hline M does not Granger Cause D & & 7.05399 & 0.00224 \\
\hline D does not Granger Cause $\mathrm{M}$ & & 0.97866 & 0.38403 \\
\hline $\mathrm{R}$ does not Granger Cause D & & 1.51426 & 0.23147 \\
\hline D does not Granger Cause R & & 0.90778 & 0.41101 \\
\hline GDP does not Granger Cause D & & 6.96313 & 0.00240 \\
\hline D does not Granger Cause GDP & & 0.28144 & 0.75608 \\
\hline
\end{tabular}

To know the nature of the effect of each variables on debt, two tools will be use, namely, Impulse Response Function (IRF), and Variance Decomposition:

Impulse Response Function (IRF) follow the time path of various Shocks experienced by the different variables included in the model, and how to reflect the response of each of these variables for any sudden shock of any variable in the model over time. The immediate response function faces the problem of arranging the variables included in the form (Kilian,2001). When a shock of one standard deviation occurs in a variable, the response function measures the impact of that on the current and future value of that variable and other variables, this is in the case that there is no correlation between random variables (Innovations), but in the case of an association between random variables, this means They are associated with an unknown or defined value, due to the variable that comes first in the VAR model.

$$
\begin{gathered}
\Delta y_{t}=\tau_{0}+\sum_{i=1}^{m} A_{i} U_{t-i} \\
y_{t}=\alpha_{0}+A_{0} U_{t}+A_{1} U_{t-1}+\ldots
\end{gathered}
$$

Variance Decomposition used to determine the amount of variation in the forecast error of each variable due to the forecast error in the variable itself and the amount of variance due to the forecast error in the other exoplanetary variables in the model, and shows the relative importance of the impact of any sudden Shock in each of the model variables on all variables in the model.

Figure (1) shows the response of debt in Jordan to a random shock of one standard deviation in the government expenditure positively and directly affects in the second period, and continues in the later periods. Government expenditure explains $(3 \%)$ of the random errors in public debt during the second 
period, and its impact increases to reach about (26\%) in the tenth period. Based on the results, government expenditure has a positive and strong impact on the debt in Jordan.

Tax negatively and weakly affects the public debt. Tax revenue explains $(0.04 \%)$ of the random errors in public debt during the second period, and its impact increases to reach about (1.4\%) in the tenth period. Fiscal policy instruments affect public debt in two different directions, the expansion of government expenditure leads to an increase in public debt, while tax revenues reduce indebtedness.

Money supply affects public debt negatively and weakly at first seven period and then turns positive. The relationship between money supply and public debt takes place through financing deficit, The results also showed that the interest rate affect negatively and weak public debt in Jordan. The monetary policy instruments affect public debt in the same directions, as the results indicate that the central bank in controlling money supply and managing interest rate helps the fiscal authority in reducing the public debt in Jordan. The results indicated that the strongest impact on public debt in Jordan is due to government expenditure.

Table 5.

Variance Decomposition.

\begin{tabular}{|c|c|c|c|c|c|c|c|}
\hline Period & S.E. & D & $\mathbf{G}$ & $\mathbf{T}$ & $\mathbf{M}$ & $\mathbf{R}$ & GDP \\
\hline 1 & 443.4108 & 100.0000 & 0.000000 & 0.000000 & 0.000000 & 0.000000 & 0.000000 \\
\hline 2 & 692.5863 & 94.03070 & 0.566136 & 0.008710 & 1.308585 & 0.726322 & 3.359550 \\
\hline 3 & 964.8729 & 83.74308 & 3.095900 & 0.049969 & 3.084011 & 1.172357 & 8.854681 \\
\hline 4 & 1214.056 & 77.12520 & 4.979022 & 0.060865 & 3.832909 & 1.686488 & 12.31552 \\
\hline 5 & 1435.125 & 70.82038 & 7.582049 & 0.044189 & 3.772985 & 3.475252 & 14.30515 \\
\hline 6 & 1629.254 & 63.63579 & 11.00612 & 0.034991 & 3.289533 & 5.596730 & 16.43684 \\
\hline 7 & 1805.913 & 56.26727 & 15.13184 & 0.044129 & 2.769502 & 6.618951 & 19.16831 \\
\hline 8 & 1975.985 & 49.66106 & 19.50040 & 0.043592 & 2.313347 & 6.511601 & 21.97000 \\
\hline 9 & 2141.086 & 44.26772 & 23.16101 & 0.345864 & 2.063415 & 6.209394 & 23.95260 \\
\hline 10 & 2312.522 & 39.30165 & 26.08486 & 1.406711 & 2.007593 & 6.362730 & 24.83645 \\
\hline \multicolumn{8}{|c|}{ Ordering: D G T M R GDP } \\
\hline
\end{tabular}

Response to One S.D. Innovations
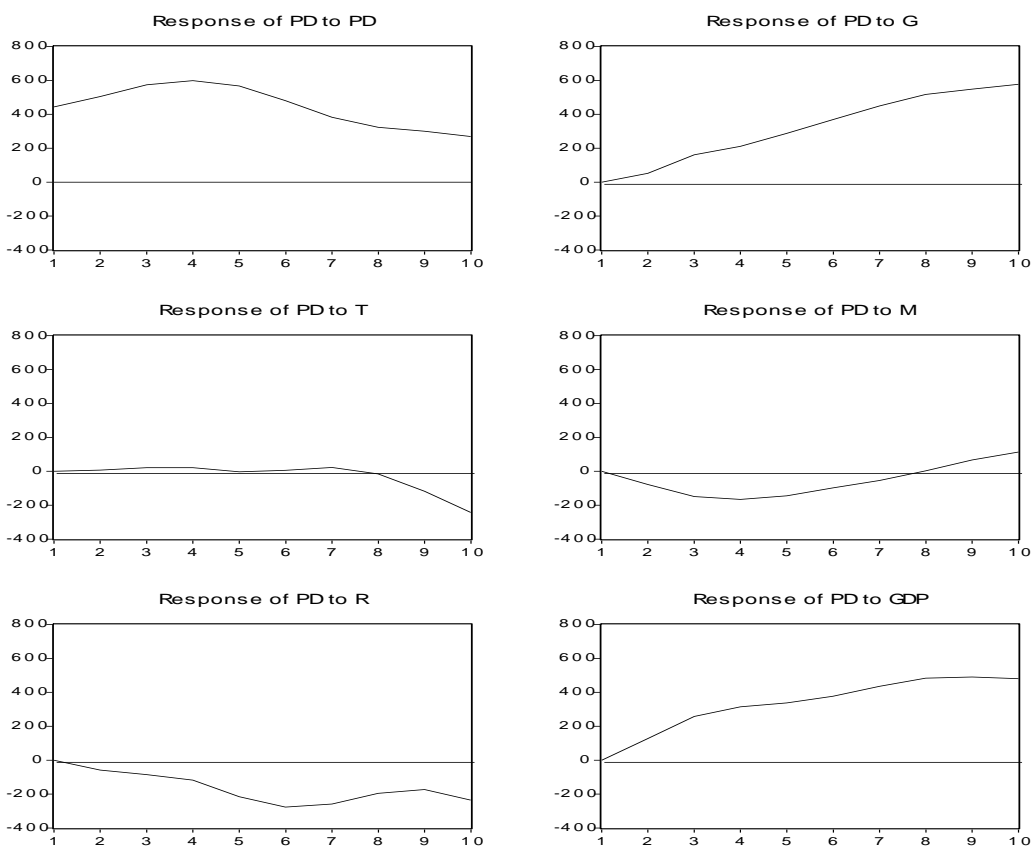

Figure 1. Impulse Response Function (IRF). 


\section{Conclusions and policy implementation}

The study aimed to analyze the effects of fiscal and monetary policies interactions on public debt management in Jordan. The estimates indicate a positive impact of government expenditures on debt and negative impact of tax on debt in short run. Money supply has a positive impact on public debt in the short run.

The results of causality showed a unidirectional causal relation between fiscal policy (government expenditure, tax) and public debt in Jordan. Also the existence of a unidirectional causal relation between money supply and public debt. The results do not indicate the existence of causal relation between the interest rate and public debt during the study period.

Government expenditure explains (26\%) of the random errors in public debt in the tenth period. Government expenditure has a positive and strong impact on the debt in Jordan. In line with, Uguru (2016) that change capital expenditure explain about $5.98 \%$ of the change on public debt, and the current expenditure explain about $(67.98 \%)$ of the change in public debt.

Tax negatively and weakly affects the public debt. Tax revenue explains (1.4\%) of the random errors in public debt in the tenth period. Money supply affects public debt negatively and weakly at first seven periods and then turns positive. The results also showed that the interest rate affect negatively and weak public debt in Jordan.

Fiscal policy instruments affect public debt in two different directions, the expansion of government expenditure leads to an increase in public debt, while tax revenues reduce indebtedness. The results indicated that the strongest impact on public debt in Jordan is due to government expenditure. Therefore, each time that the government decides to increase its expenditures, it also decides to increase its indebtedness. The study by Bader and Magableh (2009) that the chronic government deficit doesn't only decrease the government's ability to repay the debt service of the outstanding loans but also creates additional demand for new public loans. The higher debt requires considerably higher income tax rates. These distort down ward labor supply and thereby private consumption. Public consumption also decreases to avoid an even further increase in tax rates (Adam, 2011)

The monetary policy instruments affect public debt in the same directions, as the results indicate that the central bank in controlling money supply and managing interest rate helps the fiscal authority in reducing the public debt in Jordan. In line with the studies by (Al-Zoubi et al, 2013; Alalaya et al., 2017) confirmed that monetary policy and fiscal policy are relatively dependent in Jordan.

The study recommends that the need for coordination between fiscal and monetary policies and required to conform the Central Bank and the Ministry of Finance on the coordination. The need to emphasize the independence of the Central Bank on the one hand and coordination between fiscal and monetary policies must be on the other.

\section{References}

Adam, K. (2011). Government debt and optimal monetary and fiscal policy. European Economic Review, 55(1), 57-74.

Afonso, A., Alves, J, \& Balhote, R. (2019). Interactions between monetary and fiscal policies. Journal of Applied Economics, vol 22 (1), 132-151 https://doi.org/10.1080/15140326.2019.1583309

Alalaya, M., Alfarajat J., Almuhtaseb A., \& Alsheqerat F. (2017) Interaction between Monetary Policy and Fiscal Policy: An Empirical Analysis Evidence from Jordan. International Review of Management and Business Research, Vol 6 (2). $495-518$

Alawneh, A., (2017). The impact of public expenditure and public debt on taxes: A case study of Jordan. Accounting and Finance Research, 6(3), 10-23. https://doi.org/10.5430/afr.v6n3p10

Al-Zoubi, O., Saqfalhait N., \& Al-Majali, A. (2013) Interaction between Monetary and Fiscal Policy in Jordan. Journal of Economics and Economic Education Research, Vol 13 (1). 19 - 39

Bader, M., \& Magableh, I. K. (2009). An enquiry into the main determinants of public debt in Jordan: An econometric study. Dirasat, Administrative Sciences, 36(1), 181-190.

Basyal, T. (2007). Debt Management and Monetary Policy: Interrelationships. Socio-Economic Development Panorama, 1(1), 67-75. https://www.nepjol.info/index.php/sedp/article/view/1183 
Belguith, S.O., \& Omrane, H. (2017). Macroeconomic determinants of public debt growth: A case study for Tunisia. Theoretical and Applied Economics, 14 (4), 161-168

Blommestein, H. J. \& Turner, P. (2012), "Interactions Between Sovereign Debt Management and Monetary Policy Under Fiscal Dominance and Financial Instability", OECD Working Papers on Sovereign Borrowing and Public Debt Management. OECD Publishing, (3), pp 28. http://dx.doi.org/10.1787/5k9fdwrnd1g3-en

Cavalcanti, M., Vereda, L., de Doctors, R., Lima, F., \& Maynard, L. (2018). The macroeconomic effects of monetary policy shocks under fiscal rules constrained by public debt sustainability. Economic Modelling, 71, pp 184-201.

Central bank of Jordan. (2019). Annual Report, Research Department. https://www.cbj.gov.jo

Claeys, P. (2006) Policy mix and debt sustainability: evidence from fiscal Policy rules. Empirica, No 33. 89-112 DOI 10.1007/s10663-006-9009-9

Collignon, S. (2012). Fiscal policy rules and the sustainability of public debt in Europe. International economic review, 53(2), 539-567.

Demind, E. (2018). Fiscal and Monetary Policy: Coordination or Conflict? International Economic Journal, 32 ( 4) 547-571 https://doi.org/10.1080/10168737.2018.1534133

Dickey, D., \& Fuller, W. (1981), "Likelihood Ratio Statistics for Autoregressive Time Series with a Unit Root," Econometrica, 49. 1057-1072.

Doi, T., Hoshi, T., \& Okimoto, T. (2011). Japanese government debt and sustainability of fiscal policy. Journal of the Japanese and international economies, 25(4), 414-433.

Dungey, M., \& Fry, R. (2007). The Identification Fiscal and Monetary Policy in a Small Open Economy VAR. Centre for Applied Macroeconomic Analysis (CAMA) Working Paper 29. http://cama.anu.edu.au Engle, R.F., Granger, C. W. J. (1987) Co-Integration and Error Correction: Representation, Estimation, and Testing. Econometrica, 55 (2), 251-276.

Favero, C., \& Giavazzi, F. (2007). Debt and the effects of fiscal policy (No. w12822). National Bureau of Economic Research. http://www.nber.org/papers/w12822

Gaber, S., Gruevski, I., \& Gaber, V. (2013) public debt management. Perspectives of Innovations, Economics \& Business, (13)(2). P19 - 31 http://dx.doi.org/10.15208/pieb.2013.07

Golomejic, Z. R. (2007). Coordination of public debt management and running monetary policy in Croatia. Financial theory and practice, 31(2), 153-83.

Golomejic, Z. R. (2012). Coordination between the monetary and public debt management policies in Croatia. Financial Theory and Practice. 36 (2), 109-138.

Guler, A. (2019). Interaction of Monetary and Fiscal Policies in Turkey: A Dynamic Time Series Data Analysis1. Business and Economics Research Journal, 10 (5). 1039-1049 doi: 10.20409/berj.2019.220

Hakhu, A. B. (2015) Productive Public Expenditure and Debt Dynamics: An Error Correction Representation using Indian Data. Working Paper No. 2015-149, National Institute of Public Finance and Policy New Delhi http://www.nipfp.org.in

Hamilton, J. D. (1994): Time series analysis. Princeton: Princeton University Press.

Hasan, M. H, Husseinb, A.T., \& Farhan, M. N. (2020) Analysis of Government Public Debt and Its Effects on Some Economic Variables in Iraq for the Period (1991-2016) International Journal of Innovation, Creativity and Change, 13 (7), $770-782$

Hein, E. (2018). Autonomous government expenditure growth, deficits, debt, and distribution in a neoKaleckian growth model. Journal of Post Keynesian Economics, 41(2), 316-338.

Hodula. M., \& Melecky, A. (2020) Debt management when monetary and fiscal policies clash: some empirical evidence, Journal of Applied Economics, 23 ( 1), 253-280

Iiyambo, H., \& Kaulihowa, T. (2020). An assessment of the relationship between public debt, government expenditure and revenue in Namibia. Public sector economics, 44(3), 331353. https://doi.org/10.3326/pse.44.3.3

International Monetary Fund (2019). Second Review under The Extended Arrangement under The Extended Fund Facility, Requests for A Waiver of Nonobservance of Performance Criterion, An Extension of The Arrangement, and Rephrasing of Access Press Release; Staff Report; and Statement by The Executive Director for Jordan. IMF Country Report No. 19/127 https://www.imf.org/en/Publications/CR/Issues/2019/05/08/Jordan

Jang. K., \& Ogaki, M. (2004). The Effects of Monetary Policy Shocks on Exchange Rates: A Structural Vector Error Correction Model Approach. Ohio State University. J. Japanese Int. Economies 18. 99-114 doi:10.1016/S0889-1583(03)00042-X

Johansen, S. \&. Juselius, K. (1990). "Maximum Likelihood Estimation and Inference on Cointegration with Applications to Demand for Money" Oxford Bulletin of Economics and Statistics 52, 169-210.

Kilian, L. (2001). Impulse Response Analysis in Vector Autoregressions with Unknown Lag Order. Journal 
of Forecasting`, 20. $161-179$

Kirsanova, T., Srehn S., \& Vinus D., (2005). The Interactions between fiscal Policy and monetary Policy, Oxford Review of Economic Policy, 21 (4). DOI: 10.1093/oxrep/gri027

Laurens, B., \& De la Piedra, E. G., (1998). Coordination of Monetary and Fiscal Policies, IMF working paper WP /98/25. https://www.imf.org/external/pubs/ft/wp/wp9825.pdf

Le Van, C., Nguyen-Van, P., Barbier-Gauchard, A., \& Le, D. A. (2019). Government expenditure, external and domestic public debt, and economic growth. Journal of Public Economic Theory, 21(1), 116-134. https://doi.org/10.1111/jpet.12324

Lockwood, B., Philippopoulos, A., \& Snell, A. (1996). Fiscal policy, public debt stabilization and politics: Theory and UK evidence. The Economic Journal, 106(437), 894-911.

Ludvigson, S. (1996). The macroeconomic effects of government debt in a stochastic growth model. Journal of Monetary Economics, 38(1), 25-45.

Mah, G., Mongale, I. P., Mukuddem-Petersen, J., \& Petersen, M. A. (2014). Government debt in Greece: An empirical analysis. Journal of Governance and Regulation, 3(2-1), 7-17. http://doi.org/10.22495/jgr_v3_i2_c1_p1

Mah, G., Mukkudem-Petersen, J., Miruka, C., \& Petersen, M. A. (2013). The impact of government expenditure on the Greek government debt: An econometric analysis. Mediterranean Journal of Social Sciences, 4(3), 323 - 330 Doi:10.5901/mjss.2013.v4n3p323

Mason, J.W, Jayadev A. (2018). A comparison of monetary and fiscal policy interaction under 'sound' and 'functional' finance regimes. Metroeconomica, 69 (2) 488 - 508 https://doi.org/10.1111/meca.12197

Meliz, J., (1997), Some Cross-Country Evidence about debt, deficits, and the behavior of monetary and Fiscal authorities, CEPR Dissection Papers. 1653

Menguy, S. (2020). Tax Competition, Fiscal Policy, and Public Debt Levels in A monetary Union. Journal of Economic Integration, 35(3), pp. 353-395 https://doi.org/10.11130/jei.2020.35.3.353

Ministry of finance Jordan (2019). Public Debt quarterly Report, $4^{\text {th }}$ quarter. Public debt department. https://mof.gov.jo

Moore, W., \& Skeete, K. (2010). The implications of monetary policy shocks for government debt management in Barbados. CBB Working Paper 2010

Nasir, M., Ahmad, A., Ali, A. \& Rehman, F. (2010) Fiscal and Monetary Policy Coordination: Evidence from Pakistan. International Research Journal of Finance and Economics, (35), 202 - 2013

Niemann, S. \& Hagen, J. (2008) Coordination of monetary and fiscal policies: A freshlook at the issue. Swedish Economic Policy Review, 15, 89-124

Oladokun, O.O. (2015) Causal Relationship between Public Debts and Public Expenditure in Nigeria. International Journal of Management and Applied Science, 1(8), 68 - 79

Oxley, L., \& Greasley, D., (1998). Vector Autoregression, Cointegration and Causality: Testing for Causes of the British Industrial Revolution, Applied Economics, 30, pp1387-1397.

Pascal, M. (2011). Public Debt Management Fundamental Component of Public Policy, CES Working Papers, Centre for European Studies, 3(4), 571-578

Pirtea, M. G., Nicolescu, A.C. \& Mota, P.R., (2013). An empirical study on public debt's determinants: evidence from Romania. Transylvanian review of administrative sciences, 9(38), 144-157.

Reinhart, C. M., \& Rogoff, K. S. (2010 b) From Financial Crash to Debt Crisis. NBER Working Paper 15795 http://www.nber.org/papers/w15795

Reinhart, C. M., \& Rogoff, K. S.,(2010 a) Growth in a Time of Debt. NBER Working Paper No. 15639 http://www.nber.org/papers/w15639

Rezabek, P., \& Doucek, P. (2018). Monetary and Fiscal Policy Interactions in the Czech Republic. Systems, 6 (2). doi: 10.3390/systems6020025

Ribeiro, R. S., \& Lima, G. T. (2019). Government expenditure ceiling and public debt dynamics in a demand-led macromodel. Journal of Post Keynesian Economics, 42(3), 363-389. https://doi.org/10.1080/01603477.2018.1521289

Romer, C. D., \& Romer, D. H. (2010). The macroeconomic effects of tax changes: estimates based on a new measure of fiscal shocks. American Economic Review, 100(3), 763-801.

Siddiqui, K. (2019) Government Debts and Fiscal Deficits in the United Kingdom: A critical review. World Review of Political Economy, 10 (1).

Silva, C., Pires, M. \&, Terra, F. (2014) The effects of public debt management on macroeconomic equilibrium: An analysis of the Brazilian economy. Economia, 15, 174-188

Slav'yuk, R., \& Slaviuk, N. (2018). Government debt management: challenges and perspectives. Investment Management and Financial Innovations, 15(3), 143-156. doi:10.21511/imfi.15 (3).2018.12 Stock, J., \& Watson, M. (2001). Vector Autoregressions, Journal of Economic Perspectives, 15(4). 101116 
Teles, V. K., \& Mussolini, C. C. (2014). Public debt and the limits of fiscal policy to increase economic growth. European Economic Review, 66, 1-15.

Thomas, R. L. (1997), Modern Econometrics: An Introduction. Addison Wesley Longman.

Togo, E. (2007). Coordinating Public Debt Management with Fiscal and Monetary Policies: An Analytical Framework, World Bank Policy Research Working Paper, wp4369

Uguru, L. C. (2016). The link between public debt and government expenditure pattern: The Nigeria experience. IOSR Journal of business and management, 18(1), 37-41. DOI: 10.9790/487X-18113741

Waheed, A. (2017). Determinants of External Debt: A Panel Data Analysis for Oil and Gas Exporting and Importing Countries. International Journal of Economics and Financial Issues, 7(1), 234-240. 